\title{
Effects of biochar and nitrogen fertilizer on soil physicochemical properties, nitrogen use efficiency and upland rice (Oryza sativa) yield grown on an Alfisol in Southwestern Nigeria
}

\author{
Segun Oladele ${ }^{1} \cdot$ Adebayo Adeyemo $^{2} \cdot$ Moses Awodun $^{2} \cdot$ Ayodele Ajayi $^{3} \cdot$ Abayomi Fasina $^{4}$
}

Received: 24 March 2018 / Accepted: 12 February 2019 / Published online: 4 March 2019

(c) The Author(s) 2019

\begin{abstract}
Purpose Biochar and inorganic fertilizer when co-applied have been reported to increase crop yield and enhance soil fertility. However, studies on this complementary effect on soil properties and rain-fed upland rice performance in Sub-Saharan Africa are still scanty.

Methods Field factorial studies conducted over 2 years was set up to investigate the interactions between rice husk biochar and inorganic nitrogen $(\mathrm{N})$ fertilizer on a sandy clay loam Alfisol. A two-factor $(4 \times 4)$ in RCBD where rice husk biochar was incorporated at four doses, 0, 3, 6, and $12 \mathrm{t} / \mathrm{ha}^{-1}$, inorganic $\mathrm{N}$ fertilizer (urea) at four rates, 0, 30, 60 and $90 \mathrm{~N} \mathrm{~kg} / \mathrm{ha}^{-1}$, and their combinations was adopted.

Results Results showed that combination of biochar and $\mathrm{N}$ fertilizer exerted significant $(P>0.05)$ interactive effect on rice harvest index, grain and straw yield and $\mathrm{N}$-use efficiency. Interaction between biochar and $\mathrm{N}$ fertilizer increased agronomic efficiency by $140 \%$ and grain nutrient recovery by $191 \%$ over 2 years. Combination of biochar and $\mathrm{N}$ fertilizer reduced soil bulk density, increased water holding capacity and soil chemical status such as pH, N, P, K, Corg, Ca, ECEC and base saturation, all within the top $10 \mathrm{~cm}$ depth of the soil.

Conclusions Overall, the results established that rice husk biochar can be used as a soil conditioner to enhance upland rice yield on an Alfisol. The combined dose of 3-6 t/ha $\mathrm{ha}^{-1}$ biochar and $30 \mathrm{~kg} / \mathrm{ha}^{-1}$ of $\mathrm{N}$ fertilizer is thus recommended for upland rice farmers in the study area.
\end{abstract}

Keywords Rice husk biochar $\cdot$ Grain yield $\cdot$ Biomass yield $\cdot$ Soil fertility $\cdot$ Alfisol

Segun Oladele

segun.oladele@aaua.edu.ng; segunoladele14@gmail.com

1 Department of Agronomy, Adekunle Ajasin University Akungba Akoko, Akungba, PMB 01, Ondo State, Nigeria

2 Department of Crop, Soil and Pest Management, Federal University of Technology, Akure, PMB 704, Ondo State, Nigeria

3 Department of Agricultural and Environmental Engineering, Federal University of Technology, Akure PMB 704, Ondo State, Nigeria

4 Department of Soil Science and Land Resources Management, Federal University Oye-Ekiti, Oye-Ekiti, Nigeria

\section{Introduction}

Declining soil quality and nutrient losses have been a foremost bane to increased crop production and food security in sub-Saharan Africa (SSA), (Jones et al. 2013; Oladele and Awodun 2014). These problems are further exacerbated by enormous pressure on farmers to increase crop yield due to geometric population growth, climate change and the need to practice climate smart agriculture that provides beneficial ecosystem services in addition to food security (Vagen et al. 2005; Lal 2009; Awodun et al. 2017). Soils in SSA including Nigeria are faced with several challenges, such as poor agricultural practice, land degradation, soil erosion and climate change (Faloye et al. 2017). Dominant soil types in this region are greatly weathered and have acidic, low level of soil organic matter (SOM) and nutrient status (Fagbenro et al. 2012; Akingbola et al. 2016; Ajala et al. 2017). Consequently, potential crop yield has become unattainable 
without the application of inorganic fertilizer and organic materials (Mohamed et al. 2008). Farmers often use inorganic fertilizers which are expensive and scarce; therefore, they are forced to depend on alternative nutrient source such as organic manures (Awopegba et al. 2017). However, the effects of organic manure amendment on soils in SSA are short term due to rapid decomposition and less stability (Glaser et al. 2002). Furthermore, the use of mineral fertilizers also has its own downside, which includes soil acidity, leaching of nutrients, priming effect on soil organic matter, soil structure weakening, eutrophication and the huge amount of fossil fuel reserve consumed during fertilizer production (Barrow 2012). Therefore, it becomes imperative to investigate sustainable ways of managing soils in SSA and maximizing and enhancing potential crop yield. Actualizing this will require the need to amend the soil with a biological inert material such as biochar, noted for its nutrient retention characteristics and soil structure stabilization (Lehmann 2007). Biochar is derived from the thermo-degradation of organic materials in an oxygen-depleted environment with physiochemical characteristics that makes it suitable for use as a soil conditioner and carbon sequester (Shackley and Sohi 2010; Bouqbis et al. 2016). Studies by Bouqbis et al. (2016) and Ajayi and Horn (2016) reported that biochar improves soil chemical properties, decreases soil acidity, increases cation exchange capacity (CEC), improves soil aggregates, retains nutrients and helps influence water infiltration dynamics in different soil types. Rice is an important crop in Nigeria due to its large cultivated hectarage and realized tonnage (FAO 2013). It is largely cultivated in aerobic environment by resource-poor farmers, especially within areas with low mean annual rainfall of ${ }^{>} 1000 \mathrm{~mm}$. The average yield of upland rice from the farmer's field is very low at $1.0-1.7 \mathrm{t} / \mathrm{ha}^{-1}$ and far below the global world average yield of $3.53 \mathrm{t} / \mathrm{ha}^{-1}$ (FAO 2013). Increasing upland rice yield is important; however, increase in yield is presently limited by acidity, drought, low nutrient and fertilizer use efficiency (Fageria et al. 2010). Low nutrient utilization efficiency of fertilizer such as inorganic $\mathrm{N}$ fertilizer contributes to low crop yield, increased farming cost and environmental pollution. Hence, improving the efficiency of fertilizer use is of utmost importance for subsistence farmers. Enhancing N-use efficiency through the use of a sustainable soil management technique such as biochar could help raise upland rice productivity, while mitigating environmental pollution. Studies have shown that deriving an appropriate $\mathrm{N}$-recovery index (\%) could be used as an indicator for evaluating applied fertilizer use efficiency (Agegnehu et al. 2016). Previous studies reported $75 \%$ increase in maize biomass relative to NPK fertilizer alone when biochar and NPK fertilizer were combined at different ecological zones in southern China (Zhu et al. 2015). Studies by Gathorne-Hardy et al. (2009) also reported over $30 \%$ increase in barley yield when biochar and
$\mathrm{N}$ fertilizer were co-applied. Currently, studies on biochar, nitrogen fertilizer and their interactive effects on upland rice yield, soil nutrient status and nitrogen use efficiency are scanty in southwest Nigeria. To our knowledge, this is the first field-scale study addressing this research gap in the study area. This study was set up to investigate the effects of rice husk biochar, $\mathrm{N}$ fertilizer and their interaction on select soil physicochemical properties, upland rice yield and nitrogen recovery and also identify optimum combination rate of biochar and $\mathrm{N}$ fertilizer suitable for rain-fed upland rice production in the study area.

\section{Materials and method}

\section{Study area: geology and vegetation}

The study was undertaken in Akure, Ondo State, Nigeria. The location lays on latitude $7^{0} 17^{1}$ north of the Equator and on longitude $15^{0} 14^{1}$ east of the Greenwich meridian. It stands on an altitude of about $370 \mathrm{~m}$ above the sea level with hilly adjourning lands studded with granite formations believed to be of volcanic origin spreading over an area of $99,287 \mathrm{~km}^{2}$. The study area falls into the pre-Cambrian exposed order granite belt, with formation dating back as far as 600-3500 million years ago. Topographically, the site is generally flat, consisting of large quantities of red laterite and very little of mangrove swamp soil of humid tropical equatorial area. Climatically, the study area has a tropical climate and belongs to the equatorial rain forest belts (Awopegba et al. 2017). Field experiments were carried out at the experimental station of the Federal University of Technology, Akure, Department of Crop, Soil and Pest Management $\left(7^{\circ} 20^{\prime} \mathrm{N} ; 5^{\circ} 30^{\prime} \mathrm{E}\right)$ during the wet seasons of August-November, 2016 and May-August, 2017. Sixteen pre-planting composite soil samples were collected at the experimental site from a layer of $10 \mathrm{~cm}$ and $10-20 \mathrm{~cm}$. These collected samples were subjected to standard routine soil chemical analysis.

\section{Biochar production}

Rice husks were obtained from a local rice mill in Akure, Ondo State, Nigeria, and used for producing biochar in a fabricated electric biochar reactor. The rice husk was charred at $350{ }^{\circ} \mathrm{C}$ at a residence time of about $1 \mathrm{~h}$ and $15 \mathrm{~min}$. The chemical properties of the resulting biochar material were analyzed according to a standard protocol described by IBI (International Biochar Initiative (1BI) 2011). 


\section{Experimental layout}

Forty-eight subplots with a size of $2 \times 2 \mathrm{~m}$ were laid out at the experimental station. The plots were prepared using traditional tillage implements between 7 and 14 July 2016. Each subplot was raised and bunded, while a spacing of $1 \mathrm{~m}^{2}$ was allowed in between plots. Rice husk biochar was tilled into the soil in each plot according to the intended doses using a rotary hoe and rake. An improved variety of upland rice (Oryza sativa) seeds (N-U-1) widely used by farmers in the study area was manually sown by dibbling in holes on at a spacing of $0.25 \mathrm{~m}$ by $0.25 \mathrm{~m}$. Experimental treatment was a $4 \times 4$ factorial design replicated thrice, consisting of four doses of rice husk biochar, 0, 3, 6 and $12 \mathrm{t} / \mathrm{ha}^{-1}$, and four rates of nitrogen fertilizer (urea 46\%), 0, 30, 60 and $90 \mathrm{~N} \mathrm{~kg} / \mathrm{ha}^{-1}$, which resulted in 16 treatment combinations. The 16 (16) treatment combinations include: (i) F0B0, (ii) F0B3, (iii) F0B6, (iv) F0B12, (v) F90B0, (vi) F90B3, (vii) F90B6, (viii) F90B12, (ix) F60B0, (x) F60B3, (xi) F60B6, (xii) F60B12, (xiii) F30B0, (xiv) F30B3, (xv) F30B6, (xvi) and $\mathrm{F} 30 \mathrm{~B} 12$, where $\mathrm{F}$ is the nitrogen fertilizer rate and $\mathrm{B}$ is the rice husk biochar rate. The appropriate rate of nitrogen fertilizer was broadcasted on respective subplots before seeding, while basal phosphorus and potassium fertilizers were not applied as the pre-seeding soil analysis showed that the available phosphorus and potassium levels were quite adequate. Weed emergence on the plots was controlled by hand weeding and the use of hoe to prevent competition with the rice plants. At maturity, a quadrant of $1 \mathrm{~m}^{2}$ size was placed in each plot and plants within each quadrant were sampled for determination of grain and straw yield.
Grain yield $=$ actual grain yield $\times 100-\mathrm{M} / 100-\mathrm{D}$,

where $\mathrm{M}$ is the moisture content in grain (\%) and $\mathrm{D}$ is the designated moisture content (13.5\%).

Harvest index was calculated as : $\mathrm{HI}(\%)=\mathrm{Gy} / \mathrm{Sy} \times 100$,

where $\mathrm{HI}$ is the harvest index, Gy is the grain yield and Sy is the straw yield.

Post-planting soil samples were collected from each of the 48 experimental plots to obtain representative samples. These samples were similarly characterized.

\section{Plant analysis and nutrient use efficiency derivation}

Vegetative parts of rice plant from each subplot were sampled randomly at flowering stage. At each sampling, leaves and other aboveground vegetative parts were dried at $60{ }^{\circ} \mathrm{C}$ in a laboratory oven for $72 \mathrm{~h}$. Oven-dried samples were ground and passed through a $0.5 \mathrm{~mm}$ sieve to prepare a sample of $10 \mathrm{~g}$. Straw and grain samples were analyzed for $\mathrm{N}$ concentrations from each plot separately using Kjeldahl method as described by Jackson (1973). Nitrogen uptake in grain and straw was calculated by multiplying $\mathrm{N}$ content with the respective straw and grain yield $\mathrm{ha}^{-1}$. Total $\mathrm{N}$ uptake by whole biomass was obtained by summing up the $\mathrm{N}$ uptake by grain and straw and was expressed as $\mathrm{kg} \mathrm{ha}^{-1}$. Total $\mathrm{N}$ content in straw and grain samples was used for calculating N-use efficiency according to Moll et al. (1982), Ortiz-Monasterio et al. (1997) and Guarda et al. (2004). The different efficiencies of nitrogen were derived using the following formulae:

$\mathrm{AE}\left(\mathrm{kg} / \mathrm{kg}^{-1}\right)=\frac{\text { grain yield of fertilized treatment }\left(\mathrm{kg} \mathrm{ha}^{-1}\right)-\text { grain yield of unfertilized plot }\left(\mathrm{kg} \mathrm{ha}^{-1}\right)}{\text { fertilizer applied }\left(\mathrm{kg} / \mathrm{ha}^{-1}\right)}$

where $\mathrm{N}$ is the fertilizer $\mathrm{N}$ applied and $\mathrm{AE}$ is the agronomic efficiency.

N Recovery Index (\%)

$=\frac{\text { Average grain } \mathrm{N} \text { content of fertilized plots }\left(\mathrm{kg} / \mathrm{ha}^{-1}\right)-\text { average grain } \mathrm{N} \text { content of control }\left(\mathrm{kg} / \mathrm{ha}^{-1}\right)}{\text { fertilizer } \mathrm{N} \text { content }\left(\mathrm{kg} / \mathrm{ha}^{-1}\right)}$

$\times 100$. 


\section{Soil analysis}

Post-planting soil samples were collected at the soil depth of $0-10 \mathrm{~cm}$ and $10-20 \mathrm{~cm}$ and air dried, homogenized and sieved before determination of physicochemical characteristics. Kjeldahl method was applied for determining total nitrogen, and available phosphorus was determined by the Bray-2 P extractant (ammonium fluoride and concentrated hydrochloric acid) (Bray and Kurtz 1945). Soil pH was determined by using $\mathrm{pH}$ meter at a soil:water ratio of $1: 1$ (volume/volume) (Faloye et al. 2017). Exchangeable cations were determined by using ammonium acetate (Black 1965). Organic carbon was determined by wet oxidation method as described by Walkley and Black (1934); the exchangeable acidity (EA) was determined using $\mathrm{KCl}$ extraction procedure (Mclean 1965). The percent base saturation was determined by expressing the sum of the exchangeable cations as a percentage of the effective cation exchange capacity (ECEC) values. The trace elements ( $\mathrm{Mn}, \mathrm{Fe}, \mathrm{Cu}$ and $\mathrm{Zn}$ ) were determined by extracting with $0.1 \mathrm{M}$ ammonium chloride $\left(\mathrm{NH}_{4} \mathrm{Cl}\right)$ and read on the atomic absorption spectrophotometer as described by Soylak et al. (2003). Soil bulk density and water holding capacity (WHC) were measured according to methods described by Page et al. (1982) and soil texture by the Bouyoucos hydrometer method (Bouyoucos 1962).

\section{Statistical analysis}

Data collected for grain and biomass yield and soil physicochemical properties were subjected to factorial analysis of

Table 1 Initial soil and rice husk biochar properties

\begin{tabular}{lccl}
\hline Parameters & \multicolumn{2}{l}{ Soil } & \multirow{2}{*}{ Biochar } \\
\cline { 2 - 3 } & $0-10 \mathrm{~cm}$ & $10-20 \mathrm{~cm}$ & \\
\hline $\mathrm{pH}\left(\mathrm{H}_{2} \mathrm{O}\right)$ & 4.90 & 4.95 & 8.50 \\
Total organic carbon $(\%)$ & 0.37 & 0.61 & 51.13 \\
Total Nitrogen $(\mathrm{g} / \mathrm{kg})$ & 0.41 & 0.28 & 0.30 \\
$\mathrm{P}(\mathrm{mg} / \mathrm{kg})$ & 38.06 & 14.41 & 0.73 \\
$\mathrm{~K}(\mathrm{cmol} / \mathrm{kg})$ & 2.77 & 2.81 & 9.20 \\
$\mathrm{Ca}(\mathrm{cmol} / \mathrm{kg})$ & 2.92 & 1.23 & 1.25 \\
$\mathrm{Mg}(\mathrm{cmol} / \mathrm{kg})$ & 2.60 & 1.52 & 4.50 \\
$\mathrm{Na}(\mathrm{cmol} / \mathrm{kg})$ & 0.38 & 0.71 & 0.95 \\
$\mathrm{CEC}(\mathrm{cmol} / \mathrm{kg})$ & 8.67 & 6.27 & 16.00 \\
Exchangeable acidity $(\mathrm{cmol} / \mathrm{kg})$ & 0.33 & 0.41 & - \\
ECEC (cmol/kg) & 9.01 & 6.68 & - \\
$\mathrm{Base} \mathrm{saturation}(\%)$ & 96.22 & 83.23 & - \\
$\mathrm{Cu}(\mathrm{mg} / \mathrm{kg})$ & 0.09 & 0.03 & 226.5 \\
Fe $(\%)$ & 0.46 & 0.28 & 4.80 \\
$\mathrm{Zn}(\mathrm{mg} / \mathrm{kg})$ & 0.38 & 0.17 & 561.5 \\
$\mathrm{Mn}(\mathrm{mg} / \mathrm{kg})$ & 0.13 & 0.13 & 332 \\
\hline
\end{tabular}

variance (ANOVA), testing for interactive and main effects of biochar and $\mathrm{N}$ fertilizer. A separate one-way ANOVA was conducted for treatment combinations where interaction between biochar and $\mathrm{N}$ fertilizer was significant and the significant differences were assessed using Tukey's HSD test. All analyses were performed using SPSS 20th edition. The component contribution of each treatment (i.e., rice husk biochar, $\mathrm{N}$ fertilizer and rice husk biochar $\times \mathrm{N}$ fertilizer) to grain and straw yield were derived according to a mathematical equation by Zhu et al. (2014).

\section{Results and discussion}

\section{Initial soil and biochar properties}

The textural class at the study area is a sandy clay loam Typic Paleustalf Alfisol containing 68.8\% sand, 25.1\% clay and $6.1 \%$ silt at the top soil layer. It was acidic with low exchangeable acidity, low organic carbon, low CEC and low trace elements across the soil depths (Table 1).

The SEM-EDX analysis showed that rice husk biochar contains microstructure which is amorphous and heterogeneous (Fig. 1a, b). The particles also consist of higher silicon (Si) mineral aggregates, exhibiting a large degree of microporosity, containing carbon $(\mathrm{C})$, oxygen $(\mathrm{O})$, aluminum $(\mathrm{Al})$ and potassium $(\mathrm{K})$. Some of the surface pores appeared to be dominated by organic and mineral matter that was high in $\mathrm{Al} / \mathrm{Si} / \mathrm{O}$ and $\mathrm{Fe} / \mathrm{O}$ compounds.

The internal pore size of rice husk biochar was clearly seen in the SEM micrographs, exposing a variety of shapes in the form micropores and macropores. The biochar was slightly alkaline in nature with a $\mathrm{pH}$ of 8.50 , due to the high ash content, rich in magnesium, calcium and potassium and high in organic carbon (Table 1). However, for optimal performance and maximization of these benefits, biochar has to be co-applied with other sources of organic or mineral fertilizer.

\section{Effect of biochar and $\mathbf{N}$ fertilizer on grain, straw yield and harvest index}

Result showed a significant $(P<0.05)$ interaction of biochar and $\mathrm{N}$ fertilizer combination on grain yield in years of study (Table 2). However, when biochar was applied alone, rice grain yield decreased by $32.06 \%, 1.63 \%$, and $14.43 \%$ in treatments F0B3, F0B6 and F0B12 in the first year, while in the second year, grain yield was decreased by $12.20 \%$, $14.12 \%$ and $23.18 \%$. In the first year, treatment F0B 12 recorded low grain yield which averaged at $1200 \mathrm{~kg} / \mathrm{ha}$, while treatment F30B0 had the highest yield $(5,483 \mathrm{~kg} / \mathrm{ha})$. However, the F30B0 treatment was not significantly $(P<0.05)$ different from treatment F30B6 $(5350 \mathrm{~kg} / \mathrm{ha})$ 


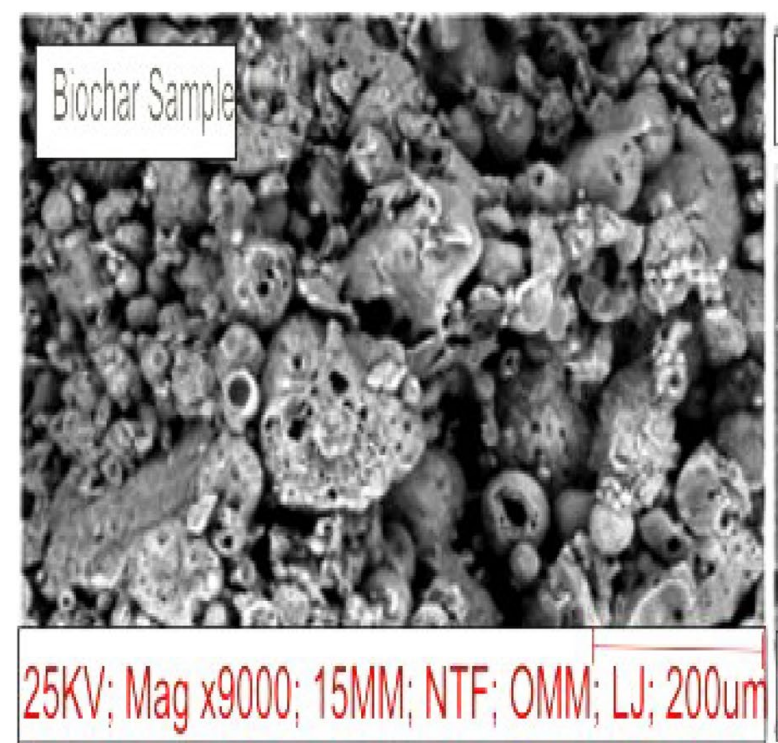

(a)

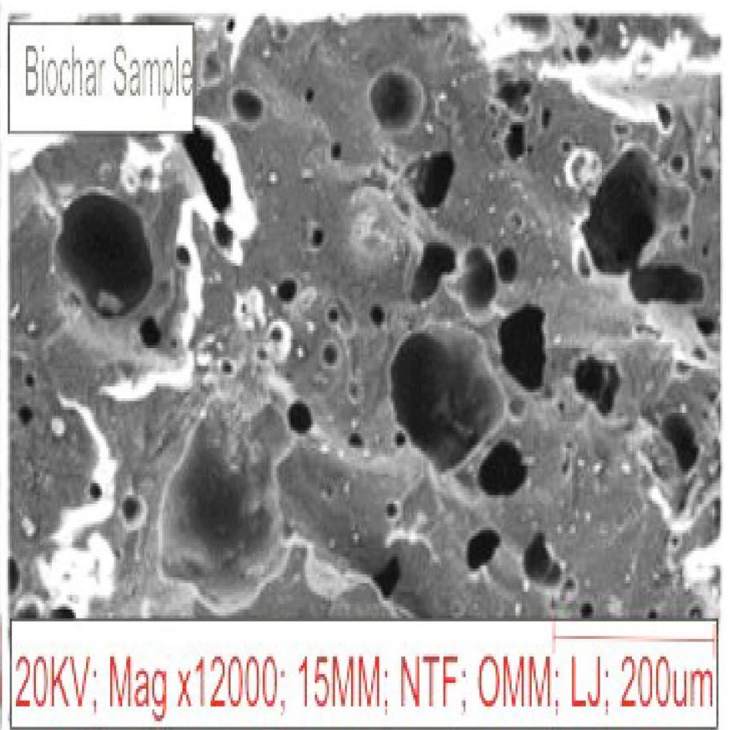

(c)

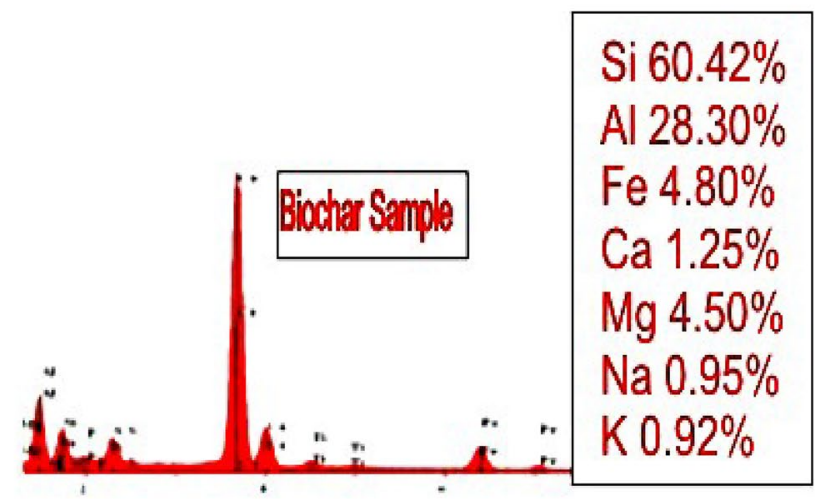

(b)

Fig. 1 a Scanning electron microscope (SEM) images of the rice husk biochar applied in the study before its incorporation into the soil. Images were taken using 27 IRPrestige-21 system and JEOL 6060 LV Scanning Electron microscope of the Environmental Sci-

(Fig. 2). Furthermore, lowest grain yield in the second year was recorded in biochar treatment F0B3 $(855 \mathrm{~kg} / \mathrm{ha})$, while the highest yield was observed in treatment F30B3 $(7390 \mathrm{~kg} /$ ha) and treatment F30B0 (7527 kg/ha), respectively. These recorded values were significantly different from the control and other treatment combinations (Fig. 2). The interaction between biochar and $\mathrm{N}$ fertilizer increased grain yield by $311,285,260,255$ and 185\% in treatments F60B6, F30B6, F90B 12 and F30B3, respectively, in the first year, and 269, $159,136,126$ and $113 \%$ in treatments F30B3, F60B6, F30B12, F30B6 and F60B3 in the second year when compared with the unfertilized treatment F0B0, suggesting a complementary interaction. $\mathrm{N}$ fertilizer application also increased grain yield by $202 \%$ in the first year, and $394 \%$ in ence Research Laboratory, Cyprus International University, Nicosia, Cyprus. $\mathrm{b}$ The EDS spectrum of the external surface of rice husk biochar with pores coated with a range of minerals, illustrating the range of different mineral phases observed on rice husk biochar surface the second year in treatment F30B0 and was statistically significant when compared to the unfertilized treatment F0B0. After 2 years of study, the application of rice husk biochar alone decreased rice grain yield, straw yield and harvest index as doses of biochar increased (Table 2). However, increasing dose of biochar was not significantly different from the control treatment. This observed trend suggests that rice husk biochar used in this study has little or no fertilizing effect and its primary role when applied as an amendment is to condition the soil for better functioning. The direct non-stimulatory effect of biochar on rice grain and straw yield in this study could also be ascribed to the nutrient immobilizing or sorption effect/high $\mathrm{C}: \mathrm{N}$ ratio and non-availability of essential nutrient such as $\mathrm{N}$ and $\mathrm{P}$ from 
Table 2 Effects of biochar and $\mathrm{N}$ fertilizer on rice grain yield, straw yield and harvest index

\begin{tabular}{|c|c|c|c|c|c|c|}
\hline \multirow[t]{2}{*}{ Factors } & \multicolumn{3}{|l|}{2016} & \multicolumn{3}{|l|}{2017} \\
\hline & Grain yield $(\mathrm{kg} / \mathrm{ha})$ & Straw yield $(\mathrm{kg} / \mathrm{ha})$ & Harvest index & Grain yield $(\mathrm{kg} / \mathrm{ha})$ & Straw yield $(\mathrm{kg} / \mathrm{ha})$ & Harvest index \\
\hline \multicolumn{7}{|c|}{ Biochar rate (t/ha) } \\
\hline 0 & $3735.00 \mathrm{a}$ & $4508.00 \mathrm{a}$ & $0.43 \mathrm{ab}$ & $4443.50 \mathrm{a}$ & $8586.58 \mathrm{a}$ & $0.44 \mathrm{a}$ \\
\hline 3 & $2537.50 \mathrm{a}$ & $4058.00 \mathrm{a}$ & $0.39 \mathrm{a}$ & $3902.75 a$ & $5463.75 a$ & $0.42 \mathrm{a}$ \\
\hline 6 & $3674.16 \mathrm{a}$ & $4220.00 \mathrm{a}$ & $0.46 \mathrm{~b}$ & $3816.25 a$ & $5342.75 a$ & $0.43 \mathrm{a}$ \\
\hline 12 & $3196.66 \mathrm{a}$ & $3579.00 \mathrm{a}$ & $0.46 b$ & $3413.25 \mathrm{a}$ & $4778.50 \mathrm{a}$ & $0.42 \mathrm{a}$ \\
\hline \multicolumn{7}{|c|}{$\mathrm{N}$ fertilizer $(\mathrm{kg} / \mathrm{ha})$} \\
\hline 0 & $1555.00 \mathrm{a}$ & $2354.20 \mathrm{a}$ & $0.40 \mathrm{a}$ & $1221.50 \mathrm{a}$ & $1709.80 \mathrm{a}$ & $0.41 \mathrm{a}$ \\
\hline 30 & $4704.20 \mathrm{c}$ & $5504.20 \mathrm{c}$ & $0.44 \mathrm{ab}$ & $6039.80 \mathrm{c}$ & $9584.80 \mathrm{c}$ & $0.45 a$ \\
\hline 60 & $3391.70 \mathrm{~b}$ & $4229.20 \mathrm{~b}$ & $0.43 \mathrm{ab}$ & $4950.20 \mathrm{c}$ & $7862.80 \mathrm{c}$ & $0.44 \mathrm{a}$ \\
\hline 90 & $3492.50 \mathrm{~b}$ & $4279.20 \mathrm{~b}$ & $0.47 b$ & $3364.20 \mathrm{~b}$ & $5014.20 \mathrm{~b}$ & $0.40 \mathrm{a}$ \\
\hline \multicolumn{7}{|l|}{$P(F$ test $)$} \\
\hline Biochar & NS & NS & $*$ & NS & NS & NS \\
\hline $\mathrm{N}$ rates & $*$ & $*$ & $*$ & $*$ & $*$ & NS \\
\hline $\mathrm{B} \times \mathrm{N}$ & $*$ & $*$ & $*$ & $*$ & $*$ & $*$ \\
\hline $\mathrm{CV}(\%)$ & 41.78 & 37.36 & 8.33 & 42.89 & 30.89 & 6.81 \\
\hline
\end{tabular}

Means in a column followed by the same letter(s) are not significantly $(P \leq 0.05)$ different according to Tukey's test, * significant, $N S$ not significant

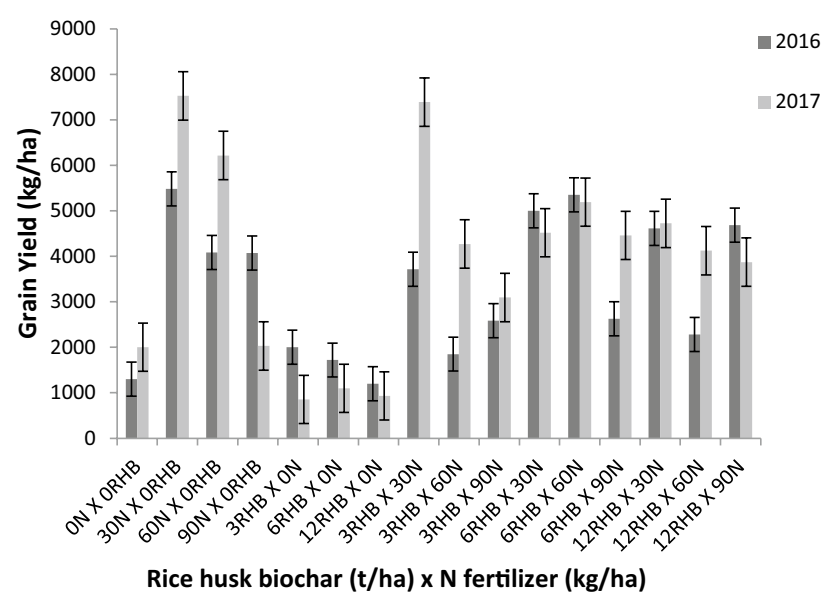

Fig. 2 Interactive effect of biochar and $\mathrm{N}$ fertilizer on rice grain yield in the first and second year

rice husk biochar for plant uptake. Findings from our study showing the negative effect of rice husk biochar on rice grain yield, straw yield and harvest index when applied alone are corroborated by Asai et al. (2009) and Karer et al. (2013) who reported a decrease in upland rice grain yield, wheat and maize grain yield when wood residue biochar at the doses of 4-16 t/ha and $72 \mathrm{t} / \mathrm{ha}$ were applied singly without complementary $\mathrm{N}$ fertilizer in Northern Laos, Vietnam and Austria, respectively. However, when doses of rice husk biochar were combined with $\mathrm{N}$ fertilizer, an increase in rice grain and straw yield was detected which indicates a sturdy complementary effect of this combination. This could be ascribed to the increased availability of nutrient to the crops as well as the liming effect biochar has on acidic soils, as most of the soils in these studies were acidic in nature. In our study, the soil type was acidic, which implies that it would benefit from the liming characteristics of biochar and also potentially offsetting the acidification that comes with its combination with $\mathrm{N}$ fertilizer. Such conditioning of the soil due to biochar application is expected to also improve soil physical condition, encourage prolific root growth and enhance air, water and gas transport. Furthermore, ameliorative effect of biochar will also enhance microbial population, increase concentrations of active soil organic matter, influence carbon and nitrogen cycling and also stimulate soil enzyme activities which influence crop growth environment (Revell et al. 2012; Ndor et al. 2015; Ajayi et al. 2016; Yao et al. 2017). Recent studies by Mete et al. (2015) and Faloye et al. (2017) have also observed an increased crop yield when biochar and mineral fertilizers were combined. Findings from our study are in conformity with Liu et al. (2012), who observed that the combination of biochar with fertilizers for soils poor in fertility had more significant effect on crop yield than the sole application of fertilizer or biochar. This could be ascribed to the improvement in soil CEC, water holding capacity (WHC), soil structure, decreased acidity, reduction in nutrient losses and increased fertilizer use efficiency due to biochar amendment (Asai et al. 2009; Ajayi and Horn 2016). The sturdy effect of biochar $\times \mathrm{N}$ fertilizer on rice grain yield at all doses of biochar $(3,6,12 \mathrm{t} /$ ha) when combined with the low rate of $\mathrm{N}$ fertilizer $(30 \mathrm{~kg} \mathrm{~N})$ could be ascribed to the conditioning influence of 
biochar and $\mathrm{N}$-use efficient rice cultivar used in this study. Significant $(P<0.05)$ interactive effect of biochar and $\mathrm{N}$ fertilizer was recorded on straw yield in both years (Table 2). Straw yield with biochar $\times \mathrm{N}$ fertilizer increased by $161 \%$ and 269\% in F30B3 compared to the control (F0B0) in the first and second year, respectively. The interaction effect on straw yield also indicates a statistically significant $(P<0.05)$ increase with combined treatments of biochar and $\mathrm{N}$ fertilizer. Straw yield was significantly increased with $\mathrm{N}$ fertilizer application $(P<0.05)$, while no significant difference was detected among treatments with biochar addition. The biochar treatment F0B12 and F0B3 had the lowest straw yield (1666 and $1197 \mathrm{~kg} / \mathrm{ha}$ ), while treatment F30B3 and F30B0 had the highest straw yield (6483 and 15,054 kg/ha) in the first and second year, respectively. Biochar doses significantly decreased straw yield by $9.98 \%, 6.385$, and $20.6 \%$ in treatments F0B3, F0B6 and F0B12 in the first year and $36.37 \%, 37.78 \%$ and $44.4 \%$, respectively, in the second year. Similar trend observed in grain yield was recorded in total straw yield when biochar was co-applied with $\mathrm{N}$ fertilizer. Our findings indicate that when rice husk biochar and $\mathrm{N}$ fertilizer were combined, an increase of over $215 \%$ in straw yield was obtained, which suggests a significant interaction between both components. This high percentage in our study was because of the low straw yield in the unamended control treatment due to the poor soil nutrient status of the control plot at the experimental site. The increase in straw yield after biochar $\times \mathrm{N}$ fertilizer co-application has also been reported in some cereal crop such as wheat (Sarma et al. 2017) and maize (Faloye et al. 2017). Studies carried out by Peng et al. (2011) and Faloye et al. (2017) corroborated our findings with a reported $146 \%$ increase in maize stover yield when biochar and inorganic fertilizer were co-applied on an Ultisol and a significant increase in cob yield by $151 \%$ on an irrigated Alfisol, respectively. Biochar $\times \mathrm{N}$ fertilizer combinations increased harvest index in treatments F90B6, F30B12 and $\mathrm{F} 30 \mathrm{~B} 6$ by $52.9 \%, 50 \%$ and $41 \%$ respectively when compared to the control (F0B0) in the first year. In the second year, treatments F30B6 recorded the highest harvest index percentage $(7.32 \%)$ when compared to the control. However, treatment F90B0 recorded the lowest harvest index when compared to other treatments. Harvest index was significantly increased with $\mathrm{N}$ fertilizer application $(P<0.05)$ only in the first year, while significant $(P<0.05)$ differences were also observed with increasing doses of biochar in singly applied biochar treatments. In the second year, a general decreasing trend in harvest index of both $\mathrm{N}$ fertilizer and biochar treatments was recorded as the rates of $\mathrm{N}$ fertilizer $(30,60,90 \mathrm{~N} \mathrm{~kg} / \mathrm{ha})$ and biochar doses $(3,6,12 \mathrm{t} / \mathrm{ha})$ increased. Findings from our study also indicate that when rice husk biochar and $\mathrm{N}$ fertilizers were co-applied, the average increase in harvest index over 2 years was $24 \%$, indicating a synergistic effect of biochar and $\mathrm{N}$ fertilizer. The translocation of assimilates or photosynthetic products by plants from source into sinks is described as harvest index. In a study conducted by Lawrence et al. (2008), they reported
Table 3 Effects of biochar and $\mathrm{N}$ fertilizer on agronomic and nitrogen use efficiency

\begin{tabular}{|c|c|c|c|c|}
\hline \multirow[t]{2}{*}{ Factors } & \multicolumn{2}{|l|}{2016} & \multicolumn{2}{|l|}{2017} \\
\hline & $\begin{array}{l}\text { Grain nitrogen recov- } \\
\text { ery index }(\%)\end{array}$ & $\begin{array}{l}\text { Agronomic efficiency } \\
\left(\mathrm{kg} / \mathrm{kg}^{-1}\right)\end{array}$ & $\begin{array}{l}\text { Grain nitrogen recov- } \\
\text { ery index }(\%)\end{array}$ & $\begin{array}{l}\text { Agronomic } \\
\text { efficiency }(\mathrm{kg} / \\
\left.\mathrm{kg}^{-1}\right)\end{array}$ \\
\hline \multicolumn{5}{|c|}{ Biochar rate $(\mathrm{t} / \mathrm{ha})$} \\
\hline 0 & $45.84 \mathrm{a}$ & $48.12 \mathrm{a}$ & $103.66 \mathrm{a}$ & $63.67 \mathrm{a}$ \\
\hline 3 & $33.50 \mathrm{a}$ & $26.09 \mathrm{a}$ & $89.92 \mathrm{a}$ & $51.83 \mathrm{a}$ \\
\hline 6 & $69.40 \mathrm{a}$ & $52.20 \mathrm{a}$ & $64.75 \mathrm{a}$ & $41.06 \mathrm{a}$ \\
\hline 12 & $53.16 \mathrm{a}$ & $42.15 \mathrm{a}$ & $72.73 a$ & $36.73 a$ \\
\hline \multicolumn{5}{|c|}{$\mathrm{N}$ fertilizer $(\mathrm{kg} / \mathrm{ha})$} \\
\hline 0 & $0.00 \mathrm{a}$ & $0.00 \mathrm{a}$ & $0.00 \mathrm{a}$ & $0.00 \mathrm{a}$ \\
\hline 30 & $117.45 \mathrm{c}$ & $102.46 \mathrm{c}$ & $204.49 c$ & $129.04 \mathrm{c}$ \\
\hline 60 & $45.93 b$ & $35.98 \mathrm{~b}$ & $85.12 b$ & $49.13 b$ \\
\hline 90 & $38.32 b$ & $30.13 b$ & $36.45 b$ & $15.13 \mathrm{a}$ \\
\hline \multicolumn{5}{|l|}{$P(F$ test $)$} \\
\hline Biochar & NS & NS & NS & NS \\
\hline $\mathrm{N}$ rates & $*$ & $*$ & $*$ & $*$ \\
\hline $\mathrm{B} \times \mathrm{N}$ & $*$ & $*$ & $*$ & $*$ \\
\hline
\end{tabular}

Means in a column followed by the same letter(s) are not significantly $(\mathrm{P} \leq 0.05)$ different according to Tukey's test, * significant, $N S$ not significant 


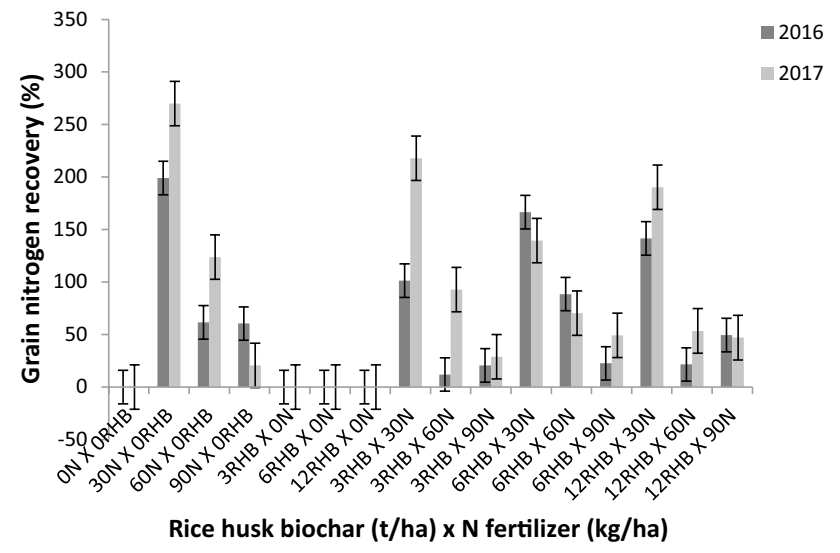

Fig. 3 Interactive effect of biochar and $\mathrm{N}$ fertilizer on rice nitrogen recovery index

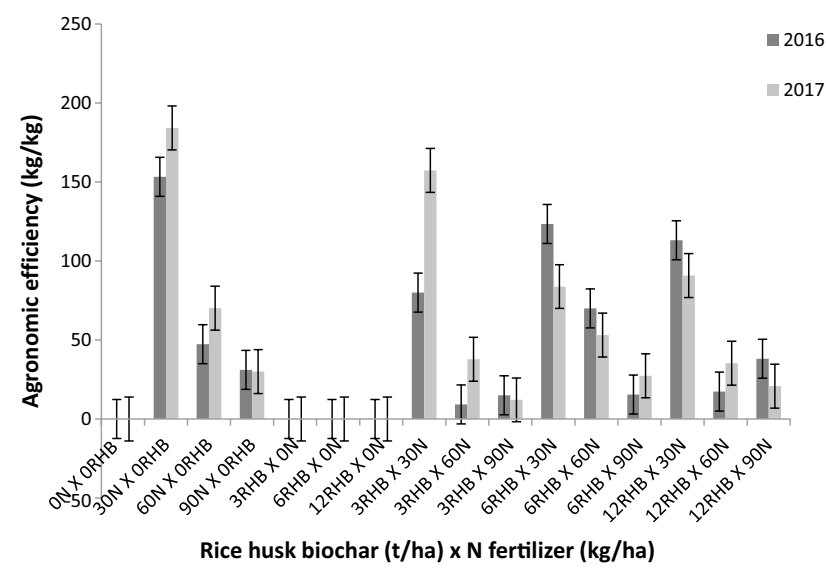

Fig. 4 Interactive effect of biochar and $\mathrm{N}$ fertilizer on rice agronomic efficiency that harvest index in cereals increased till the applied $\mathrm{N}$ fertilizer reached a plateau. However, in our study, the values recorded for harvest index were inconsistent; it appears that increasing rates of $\mathrm{N}$ fertilizer beyond $60 \mathrm{~kg} / \mathrm{ha}$ caused a decrease in harvest index, as well as doses of applied biochar beyond $6 \mathrm{t} / \mathrm{ha}$, indicating higher biomass partitioning to grain production. This trend was, however, reversed when biochar was co-applied with $\mathrm{N}$ fertilizer, as we observed an increase in harvest index suggesting more grain than straw production. We conclude that effective partitioning of photoassimilate to rice sinks rather than generation of whole plant biomass was responsible for the harvest index increase. Biochar amendment has the potential to improving nutrient retention in the soil with consequent implication for efficient use of nutrients, particularly in nutrient-deficient soils (Glaser et al. 2002; Hass et al. 2012; Alburquerque et al. 2013).

\section{Effects of biochar and $\mathbf{N}$ fertilizer on $\mathbf{N}$-use efficiency of rice}

The agronomic efficiency (AE) and nitrogen recovery index (NR) of upland rice responded significantly $(P<0.05)$ to the interactive effect of biochar and $\mathrm{N}$ fertilizer in the first and second year (Table 3). Biochar $\times \mathrm{N}$ fertilizer interaction increased agronomic efficiency (AE) in rice by $123 \%$ and grain nitrogen recovery (NR) by $166 \%$ in F30B 6 and in treatment F30B 3 by $157 \%$ and $217 \%$ when compared to the control (F0B 0$)$ in the first and second years, respectively (Figs. 3, 4). On the other hand, singly applied $\mathrm{N}$ fertilizer treatment showed a significant $(P<0.05)$ decreasing trend in $\mathrm{AE}$ and NR with increasing rates of $\mathrm{N}$ fertilizer in both years. A similar trend was also observed in biochar treatment in both years;

Table 4 Effects of biochar and $\mathrm{N}$ fertilizer on soil properties after rice harvest

\begin{tabular}{|c|c|c|c|c|c|c|c|c|c|}
\hline \multirow[t]{2}{*}{ Factors } & \multicolumn{9}{|c|}{ Soil depth $(0-10 \mathrm{~cm})$} \\
\hline & $\mathrm{BD}\left(\mathrm{g} / \mathrm{cm}^{3}\right)$ & WHC (\%) & Soil pH $\left(\mathrm{H}_{2} \mathrm{O}\right)$ & $\mathrm{N}(\mathrm{g} / \mathrm{kg})$ & $\mathrm{P}(\mathrm{mg} / \mathrm{kg})$ & $\mathrm{K}(\mathrm{cmol} / \mathrm{kg})$ & Corg $(\%)$ & ECEC (cmol/kg) & $\mathrm{EA}(\mathrm{cmol} / \mathrm{kg})$ \\
\hline \multicolumn{10}{|c|}{ Biochar rate (t/ha) } \\
\hline 0 & $1.56 \mathrm{a}$ & $32.94 \mathrm{a}$ & $5.27 \mathrm{a}$ & $0.57 \mathrm{a}$ & $148.54 \mathrm{a}$ & $0.23 \mathrm{a}$ & $0.36 \mathrm{a}$ & $7.18 b$ & $1.85 b$ \\
\hline 3 & $1.56 \mathrm{a}$ & $32.94 \mathrm{a}$ & $6.54 b$ & $0.60 \mathrm{a}$ & $148.27 \mathrm{a}$ & $0.24 \mathrm{a}$ & $0.23 \mathrm{a}$ & $9.69 a$ & $1.10 \mathrm{ab}$ \\
\hline 6 & $1.52 \mathrm{a}$ & $34.87 \mathrm{a}$ & $6.66 \mathrm{~b}$ & $1.85 \mathrm{~b}$ & $145.60 \mathrm{a}$ & $0.30 \mathrm{~b}$ & $0.76 b$ & $9.91 \mathrm{a}$ & $1.10 \mathrm{ab}$ \\
\hline 12 & $1.48 \mathrm{a}$ & $36.87 b$ & $6.73 b$ & $1.90 \mathrm{~b}$ & $130.19 a$ & $0.31 \mathrm{~b}$ & $0.78 b$ & $12.30 \mathrm{a}$ & $0.61 \mathrm{a}$ \\
\hline \multicolumn{10}{|c|}{$\mathrm{N}$ fertilizer $(\mathrm{kg} / \mathrm{ha})$} \\
\hline 0 & $1.56 \mathrm{a}$ & $33.20 \mathrm{a}$ & $6.46 \mathrm{a}$ & $1.20 \mathrm{a}$ & $120.17 \mathrm{a}$ & $0.25 \mathrm{a}$ & $0.59 \mathrm{a}$ & $7.57 \mathrm{~b}$ & $1.00 \mathrm{a}$ \\
\hline 30 & $1.56 \mathrm{a}$ & $33.51 \mathrm{ab}$ & $6.35 \mathrm{a}$ & $1.33 \mathrm{a}$ & $151.24 b$ & $0.28 \mathrm{a}$ & $0.56 a$ & $10.21 \mathrm{a}$ & $1.00 \mathrm{a}$ \\
\hline 60 & $1.48 \mathrm{a}$ & $35.84 b$ & $6.28 \mathrm{a}$ & $1.17 \mathrm{a}$ & $150.36 \mathrm{~b}$ & $0.29 \mathrm{a}$ & $0.46 \mathrm{a}$ & $10.12 \mathrm{a}$ & $1.00 \mathrm{a}$ \\
\hline 90 & $1.50 \mathrm{a}$ & $35.08 \mathrm{ab}$ & $6.10 \mathrm{a}$ & $1.22 \mathrm{a}$ & $150.82 b$ & $0.26 \mathrm{a}$ & $0.52 \mathrm{a}$ & $11.18 \mathrm{a}$ & $1.66 \mathrm{a}$ \\
\hline \multicolumn{10}{|c|}{$P(F$ test $)$} \\
\hline $\mathrm{B}$ & NS & $*$ & $*$ & $*$ & NS & $*$ & $*$ & NS & $*$ \\
\hline $\mathrm{N}$ & NS & $*$ & NS & NS & $*$ & NS & NS & NS & NS \\
\hline $\mathrm{B} \times \mathrm{N}$ & $*$ & $*$ & $*$ & $*$ & $*$ & $*$ & $*$ & $*$ & $*$ \\
\hline
\end{tabular}


Table 5 Effects of biochar (RHB), $\mathrm{N}$ fertilizer and interaction of biochar $\times \mathrm{N}$ fertilizer on soil properties after rice harvest

\begin{tabular}{llll}
\hline Factors & \multicolumn{2}{l}{ Soil depth $(0-10 \mathrm{~cm})$} & \\
\cline { 2 - 4 } & $\mathrm{Ca}(\mathrm{cmol} / \mathrm{kg})$ & $\mathrm{Mg}(\mathrm{cmol} / \mathrm{kg})$ & $\begin{array}{l}\text { Base } \\
\text { saturation } \\
(\%)\end{array}$ \\
\hline Biochar rate $(\mathrm{t} / \mathrm{ha})$ & & \\
0 & $2.74 \mathrm{c}$ & $2.08 \mathrm{~b}$ & $90.98 \mathrm{a}$ \\
3 & $4.19 \mathrm{a}$ & $3.88 \mathrm{a}$ & $90.77 \mathrm{a}$ \\
6 & $4.23 \mathrm{a}$ & $4.01 \mathrm{a}$ & $90.25 \mathrm{a}$ \\
12 & $6.11 \mathrm{~b}$ & $5.01 \mathrm{a}$ & $92.49 \mathrm{a}$ \\
$\mathrm{N}$ fertilizer $(\mathrm{kg} / \mathrm{ha})$ & & \\
0 & $2.44 \mathrm{~b}$ & $2.14 \mathrm{~b}$ & $91.45 \mathrm{a}$ \\
30 & $4.50 \mathrm{a}$ & $4.13 \mathrm{a}$ & $90.03 \mathrm{a}$ \\
60 & $4.34 \mathrm{a}$ & $4.24 \mathrm{a}$ & $89.77 \mathrm{a}$ \\
90 & $4.69 \mathrm{a}$ & $4.27 \mathrm{a}$ & $93.25 \mathrm{a}$ \\
$\mathrm{B}$ & $*$ & $\mathrm{NS}$ & $\mathrm{NS}$ \\
$\mathrm{N}$ & $\mathrm{NS}$ & $\mathrm{NS}$ & $\mathrm{NS}$ \\
$\mathrm{B} \times \mathrm{N}$ & $*$ & $\mathrm{NS}$ & $*$ \\
\hline
\end{tabular}

Means in a column followed by the same letter(s) are not significantly $(P \leq 0.05)$ different according to Tukey's test, * significant, $N S$ not significant

however, no significant difference was recorded (Table 3). The agronomic efficiency and grain N-recovery index of upland rice responded significantly to co-application of biochar and $\mathrm{N}$ fertilizer. Combination of biochar and $\mathrm{N}$ fertilizer increased AE by $140 \%$ and NR by $191 \%$ when compared to the highest dose of $\mathrm{N}$ fertilizer and the unamended treatment over 2 years (Tables 4, 5). AE and NR were increased in both years of our study when biochar was combined with $\mathrm{N}$ fertilizer. Nevertheless, higher percentage in increase was recorded in the second year. This is due to the lesser yield obtained from grain, straw and $\mathrm{N}$ uptake in the unamended treatment in the second year. At the highest $\mathrm{N}$ fertilizer rate $\left(90 \mathrm{~kg} \mathrm{~N}^{-1}\right), \mathrm{AE}$ and NR efficiency in both years was significantly decreased. However, at intermediate rates of $\mathrm{N}$ application (30 and $60 \mathrm{~kg} \mathrm{~N} \mathrm{ha}^{-1}$ ), there was a significant increase. Results from our study reveal a kind of dose-dependent interactive effects on AE and NR efficiency; both parameters depicted a decreasing trend with increase in doses of biochar $\times \mathrm{N}$ fertilizer. This observed relationship could sometimes vary with respect to the crop variety used (Guarda et al. 2004), previous soil fertilization regime, moisture availability and soil type (Fageria and Baligar 2005). In our study, increase in AE and NR efficiency via the co-application of biochar and $\mathrm{N}$ fertilizer supports the importance of using a stable nutrient-retaining material such as biochar for nutrient retention and bioavailability. Application of biochar largely improved $\mathrm{N}$ fertilizer use efficiency through positive and additive effects. Findings from this study are

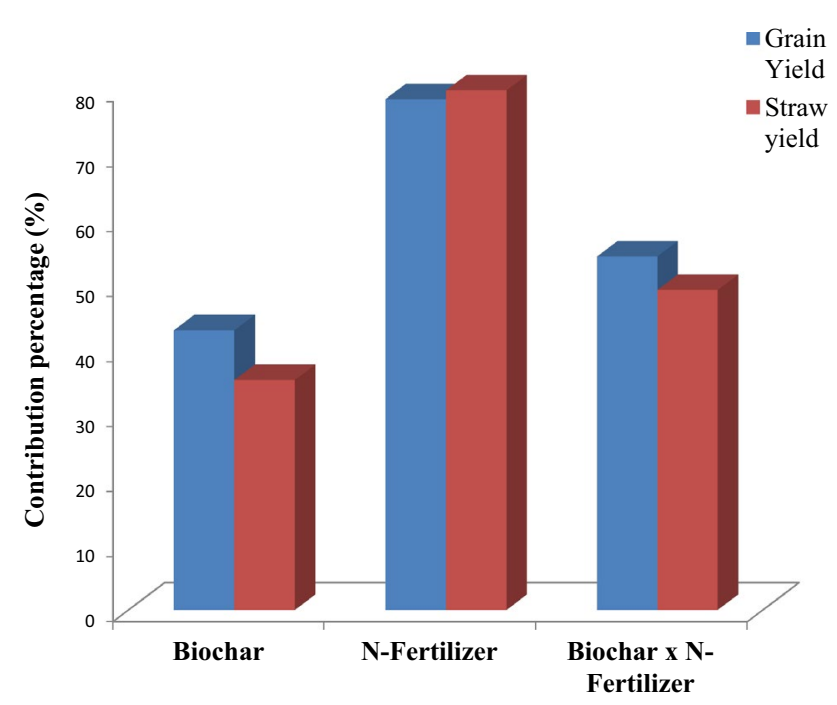

Fig. 5 Component contribution of biochar, $\mathrm{N}$ fertilizer and biochar $\times \mathrm{N}$ fertilizer to grain and straw yield

consistent with previous reports (Raun et al. 2002; Zhang et al. 2010; Haefele et al. 2011; Zhu et al. 2014; Ruisi et al. 2015; Sarma et al. 2017). Overall, the inclusion of biochar as soil conditioner in upland rice production system would improve fertilizer use efficiency and help ensure sustainable upland rice yield on a long-term basis.

\section{Component contribution of biochar and $\mathbf{N}$ fertilizer to grain and straw yield}

The component contribution of (biochar, $\mathrm{N}$ fertilizer and biochar $\times \mathrm{N}$ fertilizer) in percentage to grain and straw yield as derived using the mathematical equation postulated by Zhu et al. (2014) is shown in Fig. 5. N fertilizer,

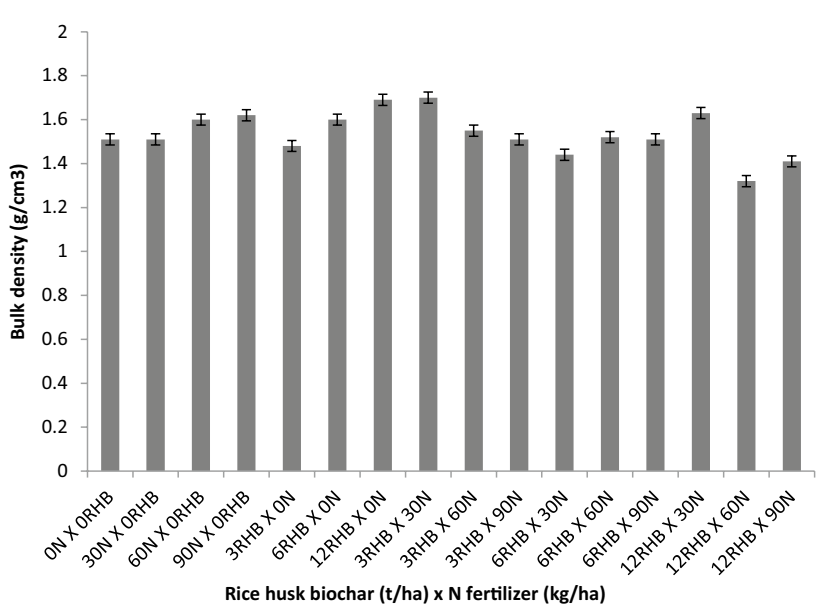

Fig. 6 Interactive effect of biochar and $\mathrm{N}$ fertilizer on soil bulk density $\left(\mathrm{g} / \mathrm{cm}^{3}\right)$ 


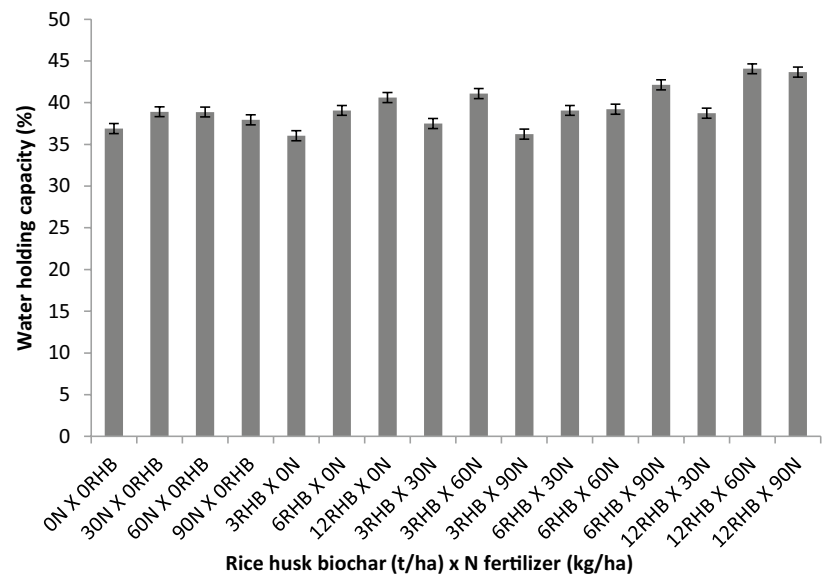

Fig. 7 Interactive effect of biochar and $\mathrm{N}$ fertilizer on soil water holding capacity (\%)

biochar and biochar $\times \mathrm{N}$ fertilizer contributed $78.6 \%$, $43.04 \%$ and over $54 \%$ to grain yield, respectively. Similarly, $\mathrm{N}$ fertilizer alone contributed more to straw yield (79.9\%), biochar contributed over $35 \%$ and a combination of biochar and fertilizer contributed about $49.24 \%$ to straw yield after 2 years of study. In our study, $\mathrm{N}$ fertilizer had more influence on grain and straw yield over 2 years in comparison to biochar and combined application of biochar and $\mathrm{N}$ fertilizer (Fig. 5). This suggests that rice husk biochar when singly applied cannot substitute for inorganic $\mathrm{N}$ fertilizer. In addition, our results confirm that coapplication of biochar and $\mathrm{N}$ fertilizer best enhanced rice grain and straw yield, than when each input was applied singly. Similar findings were corroborated by Faloye et al. (2017), who reported that the NPK fertilizer also contributed more to maize grain and stover yield than biochar alone and biochar $\times$ NPK fertilizer on a drip-irrigated Alfisol in southwestern Nigeria.

\section{Soil physicochemical properties}

Two years after biochar amendment, significant $(P<0.05)$ interactive effect of biochar and nitrogen fertilizer on soil bulk density (BD) and water holding capacity (WHC) was recorded (Tables 4, 5). Treatment F60B12 significantly reduced BD as well as increased WHC (Figs. 6, 7). The treatment was observed to have recorded the lowest BD value $\left(1.32 \mathrm{~g} / \mathrm{cm}^{3}\right)$ and the highest WHC $(44.06 \%)$ when compared to the control F0B0. The combination of biochar and $\mathrm{N}$ fertilizer decreased bulk density; this was probably due to the less dense and highly porous nature of rice husk biochar. When applied as a soil conditioner, biochar supports proliferation of soil faunas under these treatments, which in turn helps in maintaining the soil structure with proper soil aeration and water movement contributing to lowering of soil bulk density (Burrell et al. 2016). Furthermore, the large surface area and macro- and micropores structure on the external and internal surface of rice husk biochar, as viewed under a scanning electron microscope (SEM), possibly helped to store water in the pore network, thereby increasing the soil WHC. Also, the less hydrophobicity and polarity of rice husk biochar due to its conditioning after pyrolysis in this study possibly helped improve soil aggregation (Busscher et al. 2010), which could have potentially contributed to the enhanced WHC in our study. Findings from our study are corroborated by Burrell et al. (2016) and Randolph et al. (2017), who reported similar results with an increase in WHC and reduced BD upon wood residue biochar application. At a sampled soil depth of $0-10 \mathrm{~cm}$, soil $\mathrm{pH}$ values increased as the doses of biochar were increased (Tables 4,5 ). When biochar $\times \mathrm{N}$ fertilizer was combined, treatment F0B12 and F30B12 significantly recorded the highest soil $\mathrm{pH}$ (6.95 and 6.82) level with a corresponding 2.25 and 2.12 unit increase, respectively. On the other hand, a decrease in soil $\mathrm{pH}$ was observed with increasing rates of $\mathrm{N}$ fertilizer, while increasing the dose of biochar, increased soil $\mathrm{pH}$. Co-application of biochar and $\mathrm{N}$ fertilizer caused a significant $(P<0.05)$ interactive increase of total $\mathrm{N}$, available $\mathrm{P}$, exchangeable $\mathrm{K}, \mathrm{Ca}$, Corg, ECEC and base saturation, and also reduced exchangeable acidity (EA) at a soil depth of 0-10 cm. However, no significant interactive effect of biochar $\times \mathrm{N}$ fertilizer was observed for $\mathrm{Mg}$. Biochar and $\mathrm{N}$ fertilizer significantly $(P<0.05)$ increased soil $\mathrm{N}, \mathrm{P}, \mathrm{K}$ and Corg status. Also, soil CEC and base saturation were significantly $(P<0.05)$ enhanced, whereas a reverse trend was recorded for EA. $\mathrm{N}$ fertilizer had no significant $(P>0.05)$ effect on soil total N, K, Corg, EA and base saturation. Biochar treatments, however, significantly $(P<0.05)$ increased total $\mathrm{N}, \mathrm{K}, \mathrm{Corg}, \mathrm{Ca}, \mathrm{Mg}$ and ECEC and reduced EA with increasing rates of application, while no significant difference was observed for available $\mathrm{P}$ and base saturation. Also, at soil depth of $10-20 \mathrm{~cm}$, a significant $(P<0.05)$ interactive increase of total $\mathrm{N}$, available $\mathrm{P}$, exchangeable $\mathrm{K}, \mathrm{Ca}$, organic carbon, $\mathrm{Ca}, \mathrm{Mg}, \mathrm{ECEC}$, base saturation and exchangeable acidity (EA) was observed with biochar and $\mathrm{N}$ fertilizer applications (Table 6). However, no significant interaction was recorded for soil $\mathrm{pH}$ and base saturation. Biochar treatments exerted more stimulatory influence by significantly $(P<0.05)$ increasing $\mathrm{pH}$, total $\mathrm{N}$, available $\mathrm{P}, \mathrm{Ca}, \mathrm{Mg}$, Corg and ECEC, while no significant difference was detected for $\mathrm{K}$, EA and base saturation. The combination of biochar and $\mathrm{N}$ fertilizer increased soil $\mathrm{pH}$ in our study irrespective of soil depth measured. The presence of ash and cations in biochar (Vaccari et al. 2011) helped to increase the $\mathrm{pH}$ of our acidic 


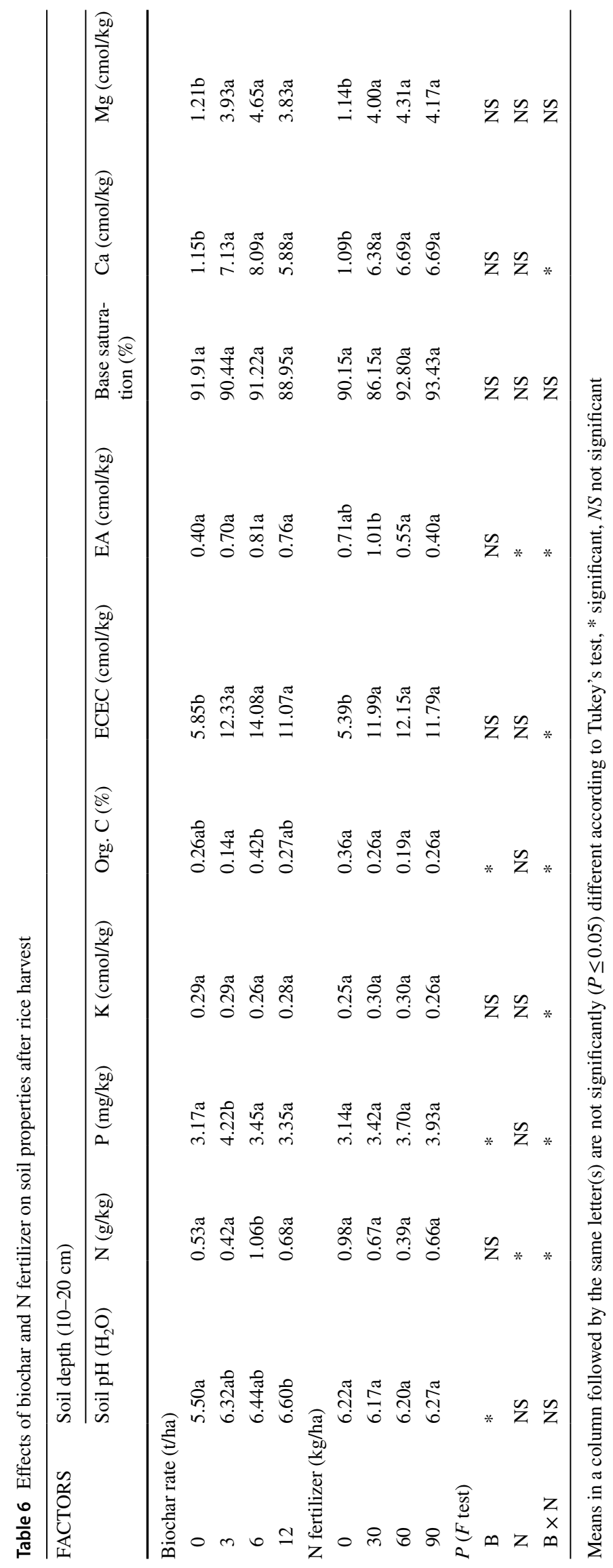


sandy clay loam soil, while offsetting the acidic reaction from applied N fertilizer (Sarma et al. 2017). This observation agrees with the findings of Revell et al. (2012), Hansen et al. (2016) and Yao et al. (2017), who all suggested that biochar can lime the soil and also mitigate the acidity effect from ammonium fertilizer application. However, when $\mathrm{N}$ fertilizer was applied singly, soil $\mathrm{pH}$ decreased with increasing $\mathrm{N}$ rates, while biochar applied singly increased soil $\mathrm{pH}$ (Tables 4, 5). Similar findings were reported by Mete et al. (2015) and Christopher et al. (2012), as this change in pH unit will enhance bioavailability of precipitated nutrients on colloidal sites such as $\mathrm{P}, \mathrm{K}^{+}, \mathrm{Ca}^{2+}$ and $\mathrm{Mg}^{2+}$. Combined application of rice husk biochar and $\mathrm{N}$ fertilizer induced significant increase in total $\mathrm{N}, \mathrm{P}$ and $\mathrm{K}$ with higher accumulation at soil depth of $0-10 \mathrm{~cm}$ (Tables 4, 5). The accumulation of these nutrients at this layer of the soil suggests easy access to nutrients for plants with shallow roots system such as rice. This is due to the sorption of nutrient elements on biochar surfaces near the plant rhizosphere which in turn leads to reduction in nutrient leaching and transportation to deeper layers of the soil thereby causing losses and ground water pollution. This indicates the positive role played by biochar in enhancing the bioavailability of these nutrients. The higher availability of $\mathrm{P}$ and $\mathrm{K}$ in biochar-amended treatments could be ascribed to the liming effect of biochar, which helped in desorption and solubilization of these nutrient ions from occluded and microbial pools of the soil (Randolph et al. 2017). Findings of increased available $P$ by Novak et al. (2009) on a biochar-amended sandy soil agrees with the increased $P$ levels observed in our study. The increase in soil CEC and ECEC after biochar amendment could be ascribed to steady, increased surface oxidation due to biochar aging that occurred in soil (Verheijen et al. 2010). This is caused by the reaction that occurs between carboxyl compounds on biochar surface with water, $\mathrm{O}_{2}$ and other chemical compounds in the soil. Also, the soil base saturation increased with an increase in the dose of added biochar and $\mathrm{N}$ fertilizer, while exchangeable acidity was decreased. This implied that a sizeable quantity of exchangeable bases was released directly from rice husk biochar and $\mathrm{N}$ fertilizer combination to the exchange site. The increase in Corg when biochar was combined with $\mathrm{N}$ fertilizer in amended treatments could be ascribed to the high labile $\mathrm{C}$ content of rice husk biochar. There is also the possibility of stimulatory increase in root biomass production and exudate release under biochar-amended treatments which increased the Corg fraction of the soil. The recalcitrant carbon fraction of the applied biochar coupled with the added $\mathrm{N}$ fertilizer could have negatively primed and reduced microbial respiration of carbon, thus consequently increasing the stability of carbon in biochar conditioned soil (Nelissen et al. 2015).

\section{Conclusions}

The combination of biochar produced from rice husk residues and nitrogen fertilizer showed clear increase in grain and biomass yield, fertilizer use efficiency and improvement of soil properties associated with rain-fed upland rice. The significant improvements observed in upland rice productivity in the study area could be ascribed to the improvement in select soil quality indices, such as BD, WHC, $\mathrm{pH}$, Corg and CEC, increase in nutrient availability, available water content and liming effect due to the high $\mathrm{pH}$ of rice husk biochar amendment. The application of biochar at low doses (3-6 t/ha) with low rate of nitrogen fertilizer $(30 \mathrm{~kg} /$ ha) notably improved $\mathrm{N}$ fertilizer use efficiency, grain and biomass yield of upland rice and soil physicochemical properties when compared to chemical fertilization with $\mathrm{N}$ fertilizer only. Our findings indicate that amending aerobic Alfisols with rice husk biochar could help increase upland rice yield, provided it is complemented with reduced amount of $\mathrm{N}$ fertilizer. Finally, our result shows that amending soils under upland rice cropping system with rice husk biochar will reduce $\mathrm{N}$ fertilization requirement, while sustainably realizing the yield potential of upland rice.

\section{Compliance with ethical standards}

Conflict of interest The authors declare that they have no conflict of interest.

Open Access This article is distributed under the terms of the Creative Commons Attribution 4.0 International License (http://creativeco mmons.org/licenses/by/4.0/), which permits unrestricted use, distribution, and reproduction in any medium, provided you give appropriate credit to the original author(s) and the source, provide a link to the Creative Commons license, and indicate if changes were made.

\section{References}

Agegnehu G, Nelson PN, Bird MI (2016) Crop yield, plant nutrient uptake and soil physicochemical properties under organic soil amendments and nitrogen fertilization on Nitisols. Soil Tillage Res 160:1-13. https://doi.org/10.1016/j.still.2016.02.003

Ajala R, Awodun M, Oladele S (2017) Effects of wood ash biomass application on growth indices and chlorophyll content of maize and lima bean intercrop. Turkish J Agric Food-Sci and Tech 5(6):614-621. https://doi.org/10.24925/turjaf.v5i6.614-621.1093

Ajayi AE, Horn R (2016) Modification of chemical and hydrophysical properties of two texturally differentiated soils due to varying magnitudes of added biochar. Soil Tillage Res 164:34-44. https ://doi.org/10.1016/j.still.2016.01.011

Ajayi AE, Holthusen D, Horn R (2016) Changes in microstructural behaviour and hydraulic functions of biochar amended soils. Soil Tillage Res 155:166-175. https://doi.org/10.1016/j.still .2015 .08 .007 
Akingbola OO, Adeyemo AJ, Oladele SO, Ojeniyi SO (2016) Physical Status and Infiltration dynamics of Tropical Alfisol as Affected by Poultry Manure. App Trop Agric 21(3):102-111

Alburquerque JA, Salazar P, Barrón V, Torrent J, Del Campillo MDC, Gallardo A, Villar R (2013) Enhanced wheat yield by biochar addition under different mineral fertilisation levels. Agron Sustain Dev 33(3):475-484. https://doi.org/10.1007/s13593-012-0128-3

Asai H, Samson BK, Stephan HM, Songyikhangsuthor K, Homma K, Kiyono Y, Inoue Y, Shiraiwa T, Horie T (2009) Biochar amendment techniques for upland rice production in Northern Laos 1 Soil physical properties, leaf SPAD and grain yield. Field Crops Res 111(2):81-84. https://doi.org/10.1016/j.fcr.2008.10.008

Awodun MA, Oladele SO, Adeyemo A (2017) Efficient nutrient use and plant probiotic microbe interaction; Probiotics in Agroecosystem. In: V. Kumar et al. (eds.), Springer Nature Singapore Pte Ltd. https://doi.org/10.1007/978-981-10-4059-7_12

Awopegba MS, Oladele S, Awodun M (2017) Effect of mulch types on nutrient composition, maize (Zea mays L) yield and soil properties of a tropical Alfisol in southwestern Nigeria. Eur J Soil Sci 6(2):121-133. https://doi.org/10.18393/ejss.286546

Barrow CJ (2012) Biochar: potential for countering land degradation and for improving agriculture. Appl Geogr 34(2):21-28. https:// doi.org/10.1016/j.apgeog.2011.09.08

Black CA (1965) Methods of Soil Analysis Part 1 and 2. American Society of Agronomy Inc, USA Bouyoucos G.J. Hydrometer method improved for making particle size analysis. Agron J 54:464-465. https://doi.org/10.1097/00010694-196511000-00020

Bouqbis L, Daoud S, Koyro HW, Kammann CI, Ainlhout LFZ (2016) Biochar from argan shells: production and characterization. Int $\mathbf{J}$ Recycl Org Waste Agricult 5(4):361-365. https://doi.org/10.1007/ s40093-016-0146-2

Bray RH, Kurtz L (1945) Determination of total, organic, and available forms of phosphorus in soils. Soil Sci 59(1):39-46

Burrell LD, Zehetner F, Rampazzo N, Wimmer B, Soja G (2016) Longterm effects of biochar on soil physical properties. Geoderma 282:96-102. https://doi.org/10.1016/j.geoderma.2016.07.019

Busscher WJ, Novak JM, Evans DE, Watts DW, Niandou MAS, Ahmedna M (2010) Influence of pecan biochar on physical properties of a Norfolk loamy sand. Soil Sci 175:10-14

Christopher D, Catherine EB, Robert CB, Mackay AE, Okure AA (2012) Comparison of kiln-derived and gasifier-derived biochars as soil amendments in the humid tropics. Biom Bioe 37:161-168. https://doi.org/10.1016/j.biombioe.2011.12.017

Fagbenro JA, Salami BT, Oshunsanya SO, Aduayi EA (2012) The potential and promise of biochar for sustainable soil productivity and crop production. Environtrop J 8:90-111

Fageria NK, Baligar VC (2005) Enhancing nitrogen use efficiency in crop plants. Adv in Agron 88:97-185. https://doi.org/10.1016/ S0065-2113(05)88004-6

Fageria NK, Morias OP, Dos Santos AB (2010) Nitrogen use efficiency of upland rice genotypes. J Plant Nut 33:1696-1711. https://doi. org/10.1080/01904167.2010.496892

Faloye OT, Alatise MO, Ajayi AE, Ewulo BS (2017) Synergistic effects of biochar and inorganic fertilizer on maize (zea mays) yield in an Alfisol under drip irrigation. Soil Tillage Res 174:214-220. https ://doi.org/10.1016/j.still.2017.07.013

FAO (2013) Faostat 2013 Food and Agriculture Organization (FAO), Rome, Italy http://faostat.fao.org

Gathorne-Hardy A, Knight J, Woods J (2009) Biochar as a soil amendment positively interacts with nitrogen fertilizer to improve barley yields in the UK. IOP Conf Ser Earth Environ Sci 6(37):372052. https://doi.org/10.1088/1755-1307/6/7/372052

Glaser B, Lehmann J, Zech W (2002) Ameliorating physical and chemical properties of highly weathered coils in the tropics with Charcoal—a review. Biol Fert Soils 35(4):219-230. https://doi. org/10.1007/s00374-002-0466-4
Guarda G, Padovan S, Delogu G (2004) Grain yield, nitrogen-use efficiency and baking quality of old and modern Italian breadwheat cultivars grown at different nitrogen levels. Eur J Agron 21:181-192. https://doi.org/10.1016/j.eja.2003.08.001

Haefele SM, Konboon Y, Wongboon W, Amarante S, Maarifat AA, Pfeiffer EM, Knoblauch C (2011) Effects and fate of biochar from rice residues in rice-based systems. Field Crops Res 121:430-440. https://doi.org/10.1016/j.fcr.2011.01.014

Hansen V, Nielsen HH, Petersen CT, Mikkelsen TN, Stövera DM (2016) Effects of gasification biochar on plant-available water capacity and plant growth in two contrasting soil types. Soil Tillage Res 161:1-9. https://doi.org/10.1016/j.still.2016.03.002

Hass A, Gonzalez JM, Lima IM, Godwin HW, Halvorson JJ, Boyer DG (2012) Chicken manure biochar as liming and nutrient source for acid Appalachian soil. J Environ Qual 41(4):1096-1106. https:// doi.org/10.2134/jeq2011.0124

International Biochar Initiative (1BI) (2011) Standardized product definition and product testing guidelines for biochar that is used in soil. http://www.biochar-international.org/characterization-stand ard. Accessed Nov 2017

Jackson ML (1973) Soil Chemical Analysis. Prentice Hall Grice, Englewood Cliffs. https://doi.org/10.1002/jpln.19590850311

Jones DL, Cross P, Withers PJ, DeLuca TH, Robinson DA, Quilliam RS, Harris I, Chadwick DR, Edwards-Jones G (2013) Nutrient stripping: the global disparity between food security and soil nutrient stocks. J Appl Ecol 50:851-862. https://doi. org/10.1111/1365-2664.12089

Karer J, Barnhard W, Franz Z, Stefanie K, Gerhard S (2013) Biochar application to temperate soils: effects on nutrient uptake and crop yield under field conditions. Agric Food Sci 22:390-403

Lawrence JR, Ketterings QM, Cherney JH (2008) Effect of nitrogen application on yield and quality of corn. Agron J 100:73-79. https ://doi.org/10.2134/agronj2007.0071

Lehmann J (2007) A handful of carbon. Nature 447:143-144. https:// doi.org/10.1038/447143a

Liu J, Schulz H, Brandl S, Miehtke H, Huwe B, Glaser B (2012) Shortterm effect of biochar and compost on soil fertility and water status of a Dystric Cambisol in NE Germany under field conditions. J Plant Nut Soil Sci 175:698-707. https://doi.org/10.1002/ jpln.201100172

McLean EO (1965) Aluminum. In: Black CA (ed) Methods of Soil Analysis. American Society of Agronomy, Madison, pp 978-998

Mete FZ, Mia S, Dijkstra F, Abuyusuf A, Hossain AS (2015) Synergistic effects of biochar and NPK fertilizer on soybean yield in an alkaline soil. Pedosphere 25(5):713-719. https://doi.org/10.1016/ S1002-0160

Mohamed S, Ewees A, Sawsan SA, Seaf A, Dalia EY (2008) Improving maize grain yield and its quality grown on a newly reclaimed sandy soil by applying micronutrients, organic manure and biological inoculation. Res J Agric Biol Sci 4:537-544

Moll RH, Kamprath EJ, Jackson WA (1982) Analysis and interpretation of factors which contribute to efficiency of nitrogen utilization. Agron J 74:562-564

Ndor E, Dauda SN, Azagakui ED (2015) Response of maize varieties (Zea mays) to biochar amended soil in lafia. Nigeria Am J Exp Agric 5(6):525-531. https://doi.org/10.9734/AJEA/2015/12375

Nelissen V, Ruysschaert G, Manka'abusi D, D'hose T, Beuf KD, Al-barri B, Cornelis W, Boeckx P (2015) Impact of a woody biochar on properties of a sandy loam soil and spring barley during a two-year field experiment. Eur J Agron 62:65-78. https ://doi.org/10.1016/j.eja.2014.09.006

Novak JM, Busscher WJ, Laird DL, Ahmedna M, Watts DW, Niandou MAS (2009) Impact of biochar amendment on fertility of a southeastern coastal plain soil. Soil Sci 174:105-112. https:// doi.org/10.1097/SS.0b013e3181981d9a 
Oladele S, Awodun M (2014) Response of lowland rice to biofertilizesr inoculation and their effects on growth and yield in Southwestern Nigeria. J Agric Environ Sci 3(2):371-390

Ortiz-Monasterio I, Sayre KD, McMahon MA (1997) Genetic progress in wheat yield and nitrogen use efficiency under four nitrogen rates. Crop Sci 37:898-904. https://doi.org/10.2135/crops ci1997.0011183X003700030033x

Page AL, Miller RH, Keeney DR (1982) Methods of Soil Analysis. Agronomy Monograph 9, 2nd edn. ASA and SSSA, Madison

Peng X, Ye LL, Wang CH, Zhou H, Sun B (2011) Temperature- and duration dependent rice straw-derived biochar: characteristics and its effects on soil properties of an Ultisol in southern China. Soil Tillage Res 112(2):159-166. https://doi.org/10.1016/j.still .2011 .01 .002

Randolph P, Bansode RR, Hassan OA, Rehrah DJ, Ravella R, Reddy MR, Watts DW, Novak JM, Ahmedna M (2017) Effect of biochars produced from solid organic municipal waste on soil quality parameters. J Environ Manag 192:271-280. https://doi. org/10.1016/j.jenvman.2017.01.061

Raun WR, Solie JB, Johnson GV, Stone ML, Mullen RW, Freeman KW, Thomason WE, Lukina EV (2002) Improving nitrogen use efficiency in cereal grain production with optical sensing and variable rate application. Agron J 94(4):815-820. https://doi. org/10.2134/agronj2002.00021962009100030001x

Revell KT, Maguire RO, Agblevor FA (2012) Influence of poultry litter biochar on soil properties and plant growth. Soil Sci 177:402-408. https://doi.org/10.1097/ss.0b013e3182564202

Ruisi P, Frangipane B, Amato G, Frenda AS, Plaia A, Giambalvo D, Saia $S$ (2015) Nitrogen uptake and nitrogen fertilizer recovery in old and modern wheat genotypes grown in the presence or absence of interspecific competition. Front Plant Sci 6:1-10. https://doi.org/10.3389/fpls.2015.00185

Sarma B, Gogoi N, Bharali M, Mali P (2017) Field evaluation of soil and wheat responses to combined application of hardwood biochar and inorganic fertilizers in acidic sandy loam soil. Expl Agric 114:1-13. https://doi.org/10.1017/S0014479717000205

Shackley S, Sohi S (2010) Benefits and Issues Associated with the Application of Biochar to Soil. Department for Environment, Food and Rural Affairs, UK Government, London

Vaccari FP, Baronti S, Lugato E, Genesio L, Castaldi S, Fornasier F, Miglietta F (2011) Biochar as a strategy to sequester carbon and increase yield in durum wheat. Eur J Agron 34:231-238. https://doi.org/10.1016/j.eja.2011.01.006

Vagen TG, Lal R, Singh BR (2005) Soil carbon sequestration in subSaharan Africa: a review. Land Degrad Dev 16:53-71. https:// doi.org/10.1002/ldr.644

Verheijen F, Jeffery S, Bastos AC, Van der Velde M, Diafas I (2010) Biochar application to soils. A critical review of effects on soil properties, processes and functions. Institute for Environment and Sustainability, Joint Research Centre, European Commission, Italy. pp 45

Walkley A, Black IA (1934) An examination of the Degtjareff method for determining soil organic matter, and a proposed modification of the chromic acid titration method. Soil Sci 37(1):29-38. https ://doi.org/10.1097/00010694-193401000-00003

Yao Q, Liu J, Yu Z, Li Y, Jin J, Liu X, Wang G (2017) Changes of bacterial community compositions after 3 years of biochar application in a black soil of northeast China. App Soil Eco 113:11-21. https ://doi.org/10.1016/j.apsoil.2017.01.007

Zhang A, Cui L, Pan G, Li L, Hussain Q, Zhang X, Zheng J, Crowley D (2010) Effect of biochar amendment on yield and methane and nitrous oxide emissions from a rice paddy from Tai Lake plain, China. Agric Eco and Env 139:469-475. https://doi.org/10.1016/j. agee.2010.09.003

Zhu QH, Peng XH, Huang TQ, Xie ZB, Holden NM (2014) Effect of biochar addition on maize growth and nitrogen use efficiency in acidic red soils. Pedosphere 24(6):699-708. https://doi. org/10.1016/S1002-0160(14)60057-6

Zhu Q, Peng X, Huang T (2015) Contrasted effects of biochar on maize growth and $\mathrm{N}$ use efficiency depending on soil conditions. Int Agrophys 29(2):257-266. https://doi.org/10.1515/intag $-2015-0023$

Publisher's Note Springer Nature remains neutral with regard to jurisdictional claims in published maps and institutional affiliations.

Segun Oladele is an experienced soil scientist and agronomist with a special research interest in biochar studies and soil biogeochemistry. He holds a $\mathrm{PhD}$ degree in soil management and currently works as a researcher and lecturer in the Department of Agronomy, Adekunle Ajasin University Akungba Akoko, Nigeria.

Adebayo Adeyemo is a trained soil scientist and researcher. He has conducted numerous studies on soil chemistry, fertility, plant nutrition, and environmental soil science. He has a Dsci degree in environmental soil chemistry and currently lectures in the Department of Crop Soil and Pest Management, Federal University of Technology Akure, Nigeria.

Moses Awodun is a professor of plant nutrition and soil science; he currently lectures and conducts research at the Federal University of Technology, Akure. His research experience spans over 15 years with studies in areas of crop production, soil fertility, and plant nutrition. He holds a $\mathrm{PhD}$ degree in crop management and lots of publications to his credit.

Ayodele Ajayi is a Professor of agricultural and environmental engineering at the Federal University of Technology Akure, Nigeria. He is a vast researcher with lots of research studies on biochar and soil physics. He has over 50 publications to his credit and is presently a visiting professor and researcher to various international Universities in countries such as Brazil, Germany, etc.

Abayomi Fasina is an experienced professor of soil classification and fertility. He is presently a lecturer and researcher at the Federal University Oye-Ekiti, Nigeria. He holds a $\mathrm{PhD}$ in soil classification and has published extensively in this field with over 45 publications to his credit. 